\title{
Species of genus Martes in the Southern Urals and Trans-Urals during the Holocene
}

\author{
Anton V. Kisagulov*, Pavel A. Kosintsev \& Dmitriy O. Gimranov
}

\begin{abstract}
The study of the morphotypes of the crowns of the buccal teeth of three species of the genus Martes made it possible to trace the formation of modern ranges of pine marten M. martes, stone marten $M$. foina and sable $M$. zibellina during the second half of the Holocene. The pine marten range did not undergo any significant changes during the second half of the Holocene and included both Southern Urals and TransUrals. In the South Urals in the beginning and middle of the Late Holocene, the ranges of sable, stone marten and pine marten were overlapped. At the end of the late Holocene the sable range was shifted to the north, and the range of stone marten to the south-west, and in 18th century, only the pine marten inhabits the Southern Urals. In the second half of the Holocene until the 18th century, the Southern Trans-Urals were inhabited by only two species of the genus Martes - sable and pine marten, their ranges were sympatric. Modern boundaries of the ranges of sable, stone marten and pine marten in the Southern Urals and in the Southern Trans-Urals have been formed over the last 300 years.

How to cite this article: Kisagulov A.V., Kosintsev P.A., Gimranov D.O. 2017. Species of genus Martes in the Southern Urals and Trans-Urals during the Holocene // Russian J. Theriol. Vol.16. No.2. P.139-148. doi: 10.15298/rusjtheriol.16.2.03

KEY WORDS: Martes, morphotypes teeth, diagnosis of species, range, Holocene, Southern Ural.

Anton V. Kisagulov [akis9119@gmail.com], Institute of Plant and Animal Ecology, Ural Branch of the Russian Academy of Sciences, 8 Marta str. 202, Yekaterinburg 620144, Russia; Pavel A. Kosintsev [kpa@ipae.uran.ru], Institute of History and Archaeology, Ural Branch of the Russian Academy of Sciences; Institute of Plant and Animal Ecology, Ural Branch of the Russian Academy of Sciences, 8 Marta str. 202, Yekaterinburg 620144, Russia; Dmitriy O. Gimranov [djulfa250@rambler.ru], Institute of Plant and Animal Ecology, Ural Branch of the Russian Academy of Sciences, 8 Marta str. 202, Yekaterinburg 620144, Russia.
\end{abstract}

\section{Виды рода Martes на Южном Урале и Зауралье в голоцене}

\section{А.В. Кисагулов*, П.А. Косинцев, Д.О. Гимранов}

\begin{abstract}
РЕЗЮМЕ. Изучение морфотипов коронок щечных зубов трех видов рода Martes позволило проследить формирование современных ареалов лесной куницы M. martes, каменной куницы M. foina и соболя M. zibellina в течение второй половины голоцена. Ареал лесной куницы во второй половине голоцена не претерпел существенных изменений и включал как Южный Урал, так и Южное Зауралье. На Южном Урале в начале и середине позднего голоцена ареалы соболя и каменной куницы перекрывались. В конце позднего голоцена ареал соболя смещается на север, а ареал каменной куницы к юго-западу, и в XVIII веке только лесная куница населяет Южный Урал. Во второй половине голоцена до XVIII века Южное Зауралье населяет только два вида рода Martes соболь и лесная куница, их ареалы симпатричны. Современные границы ареалов соболя, каменной куницы и лесной куницы сформировались на Южном Урале и в Южном Зауралье за последние 300 лет.
\end{abstract}

КЛЮЧЕВЫЕ СЛОВА: Martes, морфотипы зубов, видовая диагностика, ареал, голоцен, Южный Урал.

\section{Introduction}

The fossil bones are used to understand the evolutionary history of extinct and living species, which require precise species discrimination. Ideally, species identification implies DNA analysis of the bones. Though, due to different reasons DNA analysis is not

* Corresponding author always possible and morphological identification of fossil remains is still an important method. However, there are certain taxa which include closely related species that can be difficult to discriminate. The genus Martes is one of those taxa. There are four marten species in Northern Eurasia: Martes foina (Erxleben, 1777), M. martes (L., 1758), M. melampus (Wagner, 1840) and M. zibellina (L., 1758) (see Aristov \& Baryshnikov, 2001). Their ranges partially overlapped in 


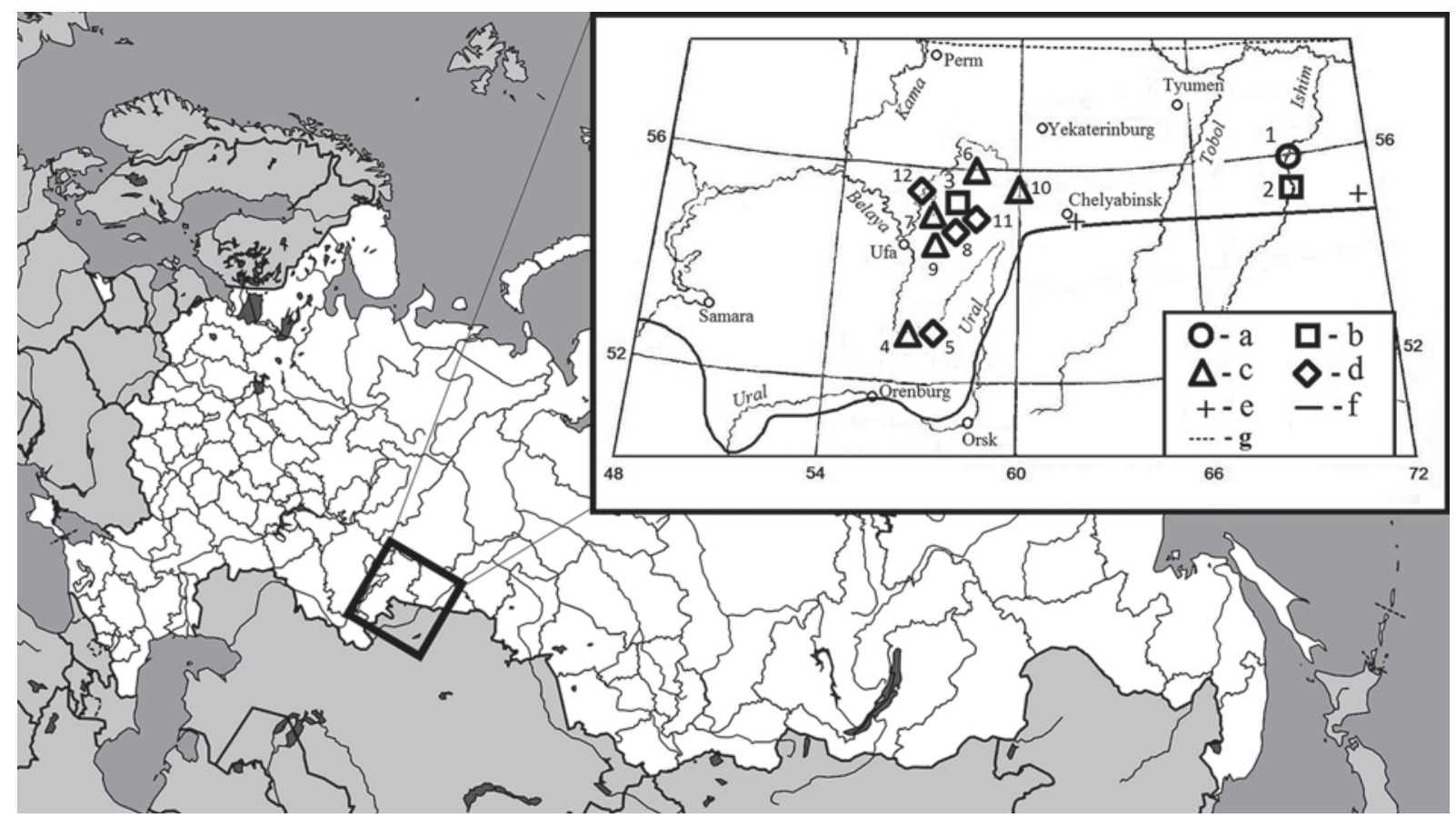

Fig. 1. Holocene localities with marten remains. Legend: a - AT, b - SB, c - SA1, d - SA2, e - data on sable hunting in the XVII-XVIII centuries (Kirikov, 1959), $\mathrm{f}$ - southern border of modern distribution of the pine marten, $\mathrm{g}$ - southern border of modern distribution of the sable. 1 - Mergen 6, 2 - Balandino, 3 - Yukalikulevo, 4 - Tashmurun (SA1), 5 Tashmurun (SA2), 6 - Serny kluch, 7 - Podpornaya, 8 - Kalinovskaya, 9 - Atysh, 10 - Berezki Vv, 11 - Staroe logovo, 12 - Barsuchy Dol.

the past (Kosintsev \& Gasilin, 2011; Gasilin et al., 2013). The same is observed in the present time (Heptner et al., 1967; Nasimovich, 1973). Correct species identification becomes essential for whose closely related species which ranges are sympatric. The postcranial skeletal elements of marten species are morphologically similar which makes their species identification rather difficult (Ambros \& Hilpert, 2005). Diagnostic features of the skull are often used for species identification (Altuna, 1973; Smirnov, 1975; Gerasimov, 1985; Aristov \& Baryshnikov, 2001; Loy et al., 2004; Monakhov, 2008, 2012; Ranyuk \& Monakhov, 2011, 2015), but in fossil material complete skulls are rare and bone fragments and isolated teeth are more common. Tooth morphotypes and their variability also can be used for discrimination between marten species (Miller, 1912; Ognev, 1931; Pavlinin, 1963; Wolsan et al., 1985, 1989; Gasilin \& Kosintsev, 2013; Gimranov \& Kosintsev, 2015).

The marten remains from the Holocene archaeological sites in the Baltic region (Paaver, 1965), the Middle Urals (Gasilin et al., 2014), the Southern Urals (Gasilin \& Gimranov, 2010; Gimranov \& Kosintsev, 2015) and south-east of Western Siberia (Devyashin et al., 2016) have been thoroughly studied in the past years. These data show that marten species inhabited the Southern Urals since the Late Pleistocene (Kosintsev \& Bachura, 2013). Remains of all three species (pine marten, stone marten, and sable) were found in the Holocene sites (Gimranov \& Kosintsev, 2015; Ko- sintsev et al., 2016). In the last three centuries only the pine marten inhabits the Southern Urals (Kirikov, 1959, 1960, 1966). Not all previously studied the remains of the genus Martes with the South Urals were the exact dating. Therefore, it was not clear when the stone marten lived in the Southern Urals and when the sable disappeared from this territory. In the Southern TransUrals, in the 18th century, there were two species pine marten and sable (Kirikov, 1959, 1966), and now lives only the pine marten (Aristov \& Baryshnikov, 2001). The marten remains from the Southern TransUrals have not been studied previously. Therefore, it is not known when the sympatric range of these species appeared in the Trans-Urals and whether the stone marten penetrated into its territory. In this paper we examined teeth of marten species from the Holocene archaeological sites in the Southern Urals and TransUrals and reconstructed the history of their modern ranges. The purpose of our study was to study the history of the formation of modern ranges of species of the genus Martes in the Southern Urals and Southern Trans-Urals. To do this, a specific diagnosis of teeth from the Holocene sites was carried out.

\section{Material and methods}

The studied region includes Southern Urals and Southern Trans-Urals. It includes the territory from the Miass River in the north to the confluence of the Or' River in the Ural River in the south; from the western 
Table 1. Frequencies of $\mathrm{m} 1$ metaconid morphotypes in modern samples of marten species.

\begin{tabular}{|c|c|c|c|c|c|c|c|c|c|}
\hline \multirow{3}{*}{ Species } & \multicolumn{8}{|c|}{ Morphotype } & \multirow{3}{*}{$n$} \\
\hline & \multicolumn{2}{|c|}{$a 1$} & \multicolumn{2}{|c|}{$a 2$} & \multicolumn{2}{|c|}{$a 3$} & \multicolumn{2}{|c|}{$a 4$} & \\
\hline & $n$ & $\%$ & $n$ & $\%$ & $n$ & $\%$ & $n$ & $\%$ & \\
\hline M. foina & - & - & 8 & 6 & 17 & 14 & 100 & 80 & 125 \\
\hline M. martes & - & - & 28 & 5 & 215 & 36 & 352 & 59 & 595 \\
\hline M. zibellina & 17 & 3 & 100 & 16 & 322 & 52 & 175 & 29 & 614 \\
\hline
\end{tabular}

slope of the Ural Mountains to the Tobol River in the east. The fossil remains are stored at the Museum of the Institute of Plant and Animal Ecology, Ural Branch, Russian Academy of Sciences (Yekaterinburg). The data on sable, pine and stone marten distribution during the last centuries were taken from published sources (Pallas, 1786, 1788; Kirikov, 1959, 1966). Subfossil marten remains yielded from 12 archaeological sites situated in the Southern Urals and Trans-Urals (Fig. 1). Total 431 subfossil teeth were studied. All sites were dated on the basis of archaeological artifacts, except Mergen 6 site which have two radiocarbon dates. All sites were assigned to chronological periods of the Holocene (Khotinsky et al., 1991):

- Atlantic (AT, 8-4.6 kyr BP) - 1 site, 69 teeth;

- Subboreal (SB, 4.6-2.6 kyr BP) - 2 sites, 5 teeth;

- Beginning of the Sub-Atlantic (SA1, 2.6-1.8 kyr BP) -5 sites, 226 teeth;

- Middle of the Sub-Atlantic period (SA2, 1.8-0.8 kyr BP) - 4 sites, 131 teeth.

We studied samples of recent skulls and lower mandibles of three marten species. Regions and the number of the studied specimens of the stone marten are as follows: Western Europe $(n=6)$, Eastern Europe $(n=$ $23)$, the Caucasus $(n=60)$, Central Asia $(n=23)$, specimens from unknown regions $(n=8)$. The sample contains 120 specimens. Regions and the number of the studied specimens of the pine marten are: Eastern Europe $(n=430)$, the Urals $(n=420)$, the Caucasus $(n=$ 140). The sample contains 990 specimens. The studied specimens of the sable are derived from the Urals $(n=$ $360)$, Siberia $(n=310)$, Kamchatka $(n=100)$, the Far East of Russia $(n=70)$. The sample contains 840 specimens. The recent specimens are stored at the collections of the Zoological Museum of the Moscow State University (Moscow), the Zoological Institute, Russian Academy of Sciences (Saint Petersburg), and the Museum of the Institute of Plant and Animal Ecology, Ural Branch, Russian Academy of Sciences (Yekaterinburg).

Only permanent teeth from the adult specimens without any crown defects were analyzed. There are no significant differences in the frequencies of $\mathrm{m} 1$ morphotypes between males and females in modern $M$. martes, M. foina, and M. zibellina $\left(\chi^{2}=1.1, p<0.01\right.$; $\chi^{2}=0.45, p<0.01 ; \chi^{2}=3.88, p<0.01$ respectively). Therefore, we did not separate male and female specimens in the subfossil samples. In our work we took into account only teeth with diagnostic features (Gimranov \& Kosintsev, 2015).

\section{Description of morphotypes}

Dental morphotypes were described according to previously published scheme (Gimranov \& Kosintsev, 2015) (Fig. 2). Also we distinguished a new group of morphotypes for $\mathrm{m} 1 \mathrm{which}$ characterized by the degree of metaconid development (Fig. 2). We examined the frequency of four new $\mathrm{ml}$ morphotypes in modern samples of M. foina $(n=125), M$. martes $(n=595)$, and M. zibellina $(n=614)$. Frequencies of $\mathrm{m} 1$ metaconid morphotypes in modern samples of different marten species are given in Table 1. The morphotype al appears exclusively in the sable which could be used for distinguishing the sable from the pine marten, and, probably, from the stone marten, even if only one tooth is available for examination. It is important when fossil material is scarce and fragmented. Frequencies of $a 2$ and $a 3$ morphotypes in modern sable are higher (16\% and $52 \%$ respectively) than those in the stone marten (6\% and $14 \%$ respectively) and pine marten (5\% and $36 \%$ respectively). The morphotype $a 4$ are more frequent in the stone $(80 \%)$ and pine marten $(59 \%)$, and less frequent in the sable (only $29 \%$ ).

Morphotypes of all teeth are denoted by uppercase Latin letters (Fig. 2). For m1, two groups of morphotypes are distinguished on different parts of the tooth (metaconid and talonid), the correlation between which has not been studied. Therefore, in order to show the isolation of the morphotypes of different parts of $\mathrm{m} 1$, the talonid morphotypes are denoted by uppercase Latin letters, and the morphotypes of the metaconid by lowercase Latin letters. Morphotypes of other teeth are indicated in uppercase Latin letters (Fig. 2).

Morphotypes P3 are characterized by lingual convexity of the crown base (Fig. 2):

$$
\begin{aligned}
& A 1 \text { - no lingual bulge; } \\
& A 2 \text { - small lingual bulge; } \\
& A 3 \text { - noticeable lingual bulge. }
\end{aligned}
$$

Morphotypes P4 are distinguished by configuration of the tooth buccal side, position of the protocone, and the number of cones on the protocone:

A1 - a concave between the protocone and parastyle; the protocone is anterior to parastyle; concave buccal outline; 


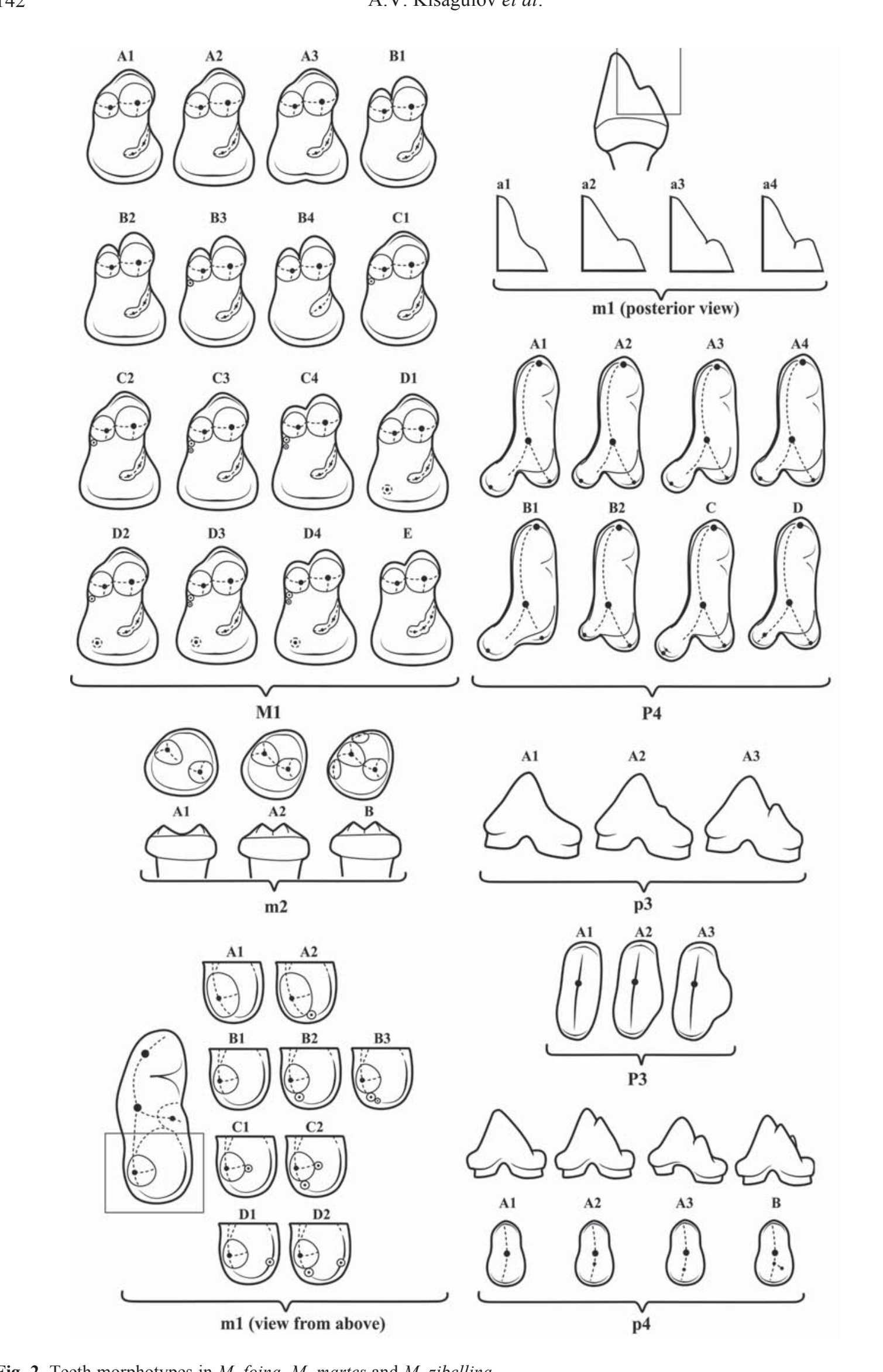


$A 2$ - a concave between the protocone and parastyle; non extends beyond protocone; concave buccal outline;

$A 3$ - a concave between the protocone and parastyle; the protocone is anterior to parastyle; no buccal concavity;

$A 4$ - a concave between the protocone and parastyle; non extends beyond protocone; no buccal concavity;

$B 1$ - no concave between the protocone and parastyle; the protocone is noticeably anterior to parastyle; no buccal concavity;

$B 2$ - undeveloped protocone; concave buccal outline. $C$ - two-cusped protocone; concave buccal outline; the protocone is anterior to parastyle.

Morphotypes of the M1 are defined by several patterns, such as the shape of the crown on its lingual and buccal sides, the presence or absence of cusps on the occlusal surface, and the crest complexity:

$A 1$ - rounded lingual and buccal outline; is present protocone and protoconule;

$A 2$ - straight lingual and rounded buccal outline; is present protocone and protoconule;

$A 3$ - heart shaped lingual and rounded buccal outline; is present protocone and protoconule;

$B 1$ - rounded lingual outline; the posterior contour of the crown shows a distinct V-shaped indentation in occlusal view; is present protocone and protoconule;

$B 2$ — straight lingual outline; the posterobuccal contour of the crown shows a distinct $\mathrm{V}$-shaped indentation in occlusal view; is present protocone and protoconule;

$B 3$ - rounded lingual outline; the posterobuccal contour of the crown shows a distinct $\mathrm{V}$-shaped indentation in occlusal view; is present protocone, protoconule and metaconule;

B4 - rounded lingual outline; the posterobuccal contour of the crown shows a distinct $\mathrm{V}$-shaped indentation in occlusal view; no paraconule; the protocone forms a massive bulge;

C1 - rounded lingual and buccal outline; is present protocone, protoconule and metaconule;

$C 2$ - straight lingual and rounded buccal outline; is present protocone, protoconule and metaconule;

C3 - straight lingual and rounded buccal outline; is present protocone, protoconule and metaconule; metaconule have two-cusped;

C4 — straight lingual outline; the posterobuccal contour of the cingulum is slightly concave; is present protocone, protoconule and metaconule, metaconule have two-cusped;

D1 - straight lingual and rounded buccal outline; is present protocone and protoconule; the hypocone is present;

D2 - straight lingual and rounded buccal outline; is present protocone, protoconule and metaconule; the hypocone is present;
D3 — straight lingual and rounded buccal outline; is present protocone and protoconule; the hypocone and two-cusped metaconule are present;

D4 - straight lingual outline; the posterobuccal contour of the cingulum is slightly concave is present protocone and protoconule, the hypocone and twocusped metaconule are present;

$E$ - straight lingual outline; the posterobuccal contour of the cingulum is slightly concave; is present protocone and protoconule, between is an additional small cusp.

Morphotypes of the $\mathrm{p} 3$ are distinguished by the degree of an additional cusp development on the protoconid distal crest:

$A 1$ - posterior accessory cusp is absent;

$A 2$ - small posterior accessory cusp is present;

$A 3$ - a well-developed posterior accessory cusp is present.

The identification of morphotypes of the $ð 4$ is based on the degree of a cusp development on the protoconid distal crest and on the presence of an additional cusp on the lingual side of the tooth:

$A 1$ - posterior accessory cusp is absent;

$A 2$ - the posterior accessory cusp has highest position;

$A 3$ - the posterior accessory cusp has lower position;

$B$ - the posterior accessory cusp has highest position an additional lingual cusp is present.

In $\mathrm{m} 1$, differences are based on the talonid occlusal surface. The morphotypes were differentiated on the basis of the hypoconid robustness and the presence, as well as relative position of additional cusps on the talonid:

A1 - the distinct massive hypoconid occupies approximately a half of the talonid basin;

$A 2$ - the hypoconulid is present to the massive hypoconid;

$A 1$ - a small-sized hypoconid;

$A 2$ - the hypoconulid is present to the hypoconid;

$A 3$ - two-cusped hypoconulid is present;

$C 1$ - an additional cusp at the inner edge of the hypoconid; hypoconid small-sized;

$C 2$ - the hypoconulid is present; an additional cusp at the inner edge of the hypoconid; hypoconid smallsized;

D1 - the hypoconid is similar in size to those in groups $\mathrm{B}$ and $\mathrm{C}$; the entoconid is present;

D2 - the hypoconulid and entoconid are both present; hypoconid small-sized.

Also we distinguished a new group of morphotypes for $\mathrm{m} 1$ which characterized by the degree of metaconid development:

$a 1$ - the metaconid is crest-like; there is no notch between protoconid and metaconid; 
a2 - the metaconid resembles a shelf without the apex, the notch between protoconid and metaconid is poorly visible;

a3 - the metaconid resembles a bulge with the apex, the notch between protoconid and metaconid is clearly visible;

a4 - the metaconid forms a separate cusp with the peak, the notch between protoconid and metaconid is distinct.

Morphotypes of the $\mathrm{m} 2$ were identified according to relative position of the protoconid and metaconid, as well as the presence of the paraconid and hypoconid:

$A 1$ - the protoconid and metaconid are at considerable distance from each other;

$A 2$ - protoconid and metaconid closely-spaced, forming a crest;

$\hat{A}$ - the protoconid, metaconid, paraconid, and hypoconid are present; the protoconid and metaconid are closely spaced.

\section{Results and discussion}

Species identification of marten teeth from the Holocene archaeological sites was made on the basis of data obtained for recent sable, pine and stone martens. The distribution of $\mathrm{m} 1$ metaconid morphotypes in the Holocene samples from the Southern Urals and TransUrals are shown in the Table 2.

The earliest marten remains were found at Mergen 6 locality and were dated between middle and the end of the Atlantic period. In this sample no teeth with species-specific morphotypes were found (Table 2). Frequencies of $\mathrm{P} 3, \mathrm{i} 3, \mathrm{p} 3$ and $\mathrm{m} 1$ morphotypes in subfossil material are more typical for the pine marten and the sable than for the stone marten. Morphotype $A 2$ dominates on p4 (61\%), while morphotypes $A 1$ and $A 3$ occur in $13 \%$ and $26 \%$ respectively (Table 3 ). Frequency of A2 morphotype in modern M. zibellina is $67 \%$, while in modern $M$. martes and $M$. foina it is $6 \%$ and $1 \%$ respectively (Gimranov \& Kosintsev, 2015).

The frequency of $A 2$ morphotype in the sample from Mergen 6 fit the modern sable pattern. Although number of specimens is small $(n=23)$, high frequency of $A 2$ morphotype strongly indicates the presence of the sable. In general, morphotype distribution in Mergen 6 sample (Table 2) suggests the presence of pine marten, sable, and, with very low probability, the stone marten.

The number of available material from archaeological sites dated to the Sub-Boreal period is very low (Table 2). Morphotype $C 2$ on M1 tooth from Yukalikulevo indicates that this tooth belonged to a pine marten or sable, but not a stone marten. Other tooth morphotypes does not allow reliable species identification.

Five archaeological sites (Serny kluch, Podpornaya, Atysh, Berezki Vv and Tashmurun (SA1)) are dated to the beginning of the Sub-Atlantic period. All of them are located in the Southern Urals (Fig. 1). In Podpornaya site one $\mathrm{m} 1$ with $A 2$ morphotype (Table 3 ) was found which is specific solely for the stone marten (Gimranov \& Kosintsev, 2015). Previously a mandible belonged to the stone marten and two $\mathrm{m} 1$ with $C 2$ morphotype which are absent in modern stone marten were described from the same locality (Gimranov \& Kosintsev, 2015). On the basis of these findings we can assume that remains from Podpornaya site belongs to the stone marten, sable and/or pine marten. Two P4 from Atysh demonstrate morphotype $D$ which is occurring in the sable $(15 \%)$ and stone marten $(2 \%)$ but absent in the pine marten. The p4 that also found in Atysh is characterized by high frequencies of morphotype $A 2-83 \%$ (Table 3 ). The frequencies of morphotypes $A 1$ and $A 3$ are $13 \%$ and $3 \%$ respectively. As it was previously mentioned, high frequencies of morphotype $A 2$ on $\mathrm{p} 4$ is common for the sable (Table 3 ). The number of specimens in subfossil sample is rather small $(n=30)$, though high frequency of morphotype $A 2$ indicates the presence of the sable teeth. The distribution of P3, İ1, i3, p3 and $\mathrm{m} 2$ morphotypes is more typical for the pine marten and the sable than for the stone marten. We can conclude that in the beginning of the Late Holocene three marten species - pine marten, stone marten and sable - inhabited the Southern Urals.

Four archaeological sites (Kalinovskaya, Staroe logovo, Barsuchy Dol and Tashmurun (SA2)) are dated to the mid-Sub-Atlantic period. Number of teeth from these sites is small which makes reliable species identification rather difficult. No morphotype $a 1$ on $\mathrm{m} 1$ that are species-specific for the sable was identified (Table 2 ). Though, recently published data suggest that stone marten still lived in the area during SA2. The mandible from Kalinovskaya cave was attributed to the stone marten based on morphometric analysis (Gasilin \& Kosintsev, 2013).

The pine marten's range did not have major changes during historical times - the species lived in the Southern Urals and Trans-Urals till the present (Kirikov, 1959, 1966; Devyashin et al., 2016). The sable inhabited the Southern Trans-Urals in the XVII and XVIII centuries, but became extinct at the beginning of XX century (Pallas, 1786; 1788; Kirikov, 1959; 1966). In the Southern Urals sable became extinct before the historical times. No evidence of stone marten occurrence is available for the Southern Urals and TransUrals over the last centuries (Kirikov, 1959; 1966).

\section{Conclusion}

The study of the morphotypes of the crowns of the buccal teeth of three species of the genus Martes made it possible to trace the formation of modern ranges of pine marten, stone marten and sable during the second half of the Holocene. The pine marten range did not undergo any significant changes during the second half of the Holocene and included both Southern Urals and Trans-Urals. In the South Urals, sable and stone marten are found in the sites of the first half of the Late Holocene. At this time, the southern boundary of the 
Table 2. Distribution of the teeth morphotypes in samples from the Holocene localities: 1 - Mergen 6, 2 - Balandino, 3 - Yukalikulevo, 4 - Tashmurun (SA1), 5 - Tashmurun (SA2), 6 - Serny kluch, 7 - Podpornaya, 8 - Kalinovskaya, 9 - Atysh, 10 - Berezki Vv, 11 - Staroe logovo, 12 - Barsuchy Dol.

\begin{tabular}{|c|c|c|c|c|c|c|c|c|c|c|c|c|c|}
\hline \multirow{2}{*}{ Tooth } & \multirow{2}{*}{ Morphotype } & \multicolumn{12}{|c|}{ Locality } \\
\hline & & 1 & 2 & 3 & 4 & 5 & 6 & 7 & 8 & 9 & 10 & 11 & 12 \\
\hline \multirow{3}{*}{ P3 } & $A 1$ & & & & & & & 1 & 1 & & & & \\
\hline & $A 2$ & & & & & 1 & & 3 & 1 & 5 & & & \\
\hline & $A 3$ & 1 & & & & & & & & 8 & & 1 & \\
\hline \multicolumn{2}{|r|}{ Total } & 1 & 0 & 0 & 0 & 1 & 0 & 4 & 2 & 13 & 0 & 1 & 0 \\
\hline \multirow{5}{*}{ P4 } & $A 1$ & & & 1 & & 1 & & & 1 & 8 & & & \\
\hline & $A 2$ & & & 1 & & 1 & & & 2 & 2 & & & \\
\hline & $A 3$ & & & & & & & & & 7 & & 1 & \\
\hline & $A 4$ & & & & & & & & & 3 & & & 1 \\
\hline & $D$ & & & & & & & & & 2 & & & \\
\hline \multicolumn{2}{|r|}{ Total } & 0 & 0 & 2 & 0 & 2 & 0 & 0 & 3 & 22 & 0 & 1 & 1 \\
\hline \multirow{4}{*}{ M1 } & $A 1$ & & & & & & & & & 1 & & & \\
\hline & $A 2$ & & & 1 & & 1 & & & 5 & 9 & & & 1 \\
\hline & $A 3$ & & & & & & & & & 1 & & & \\
\hline & $C 2$ & & & 1 & & & & & & 2 & & 1 & \\
\hline \multicolumn{2}{|r|}{ Total } & 0 & 0 & 2 & 0 & 1 & 0 & 0 & 5 & 13 & 0 & 1 & 1 \\
\hline $\mathrm{i3}$ & $A 2$ & 1 & & & & & & & & 2 & & & \\
\hline \multicolumn{2}{|r|}{ Total } & 1 & & & & & & & & 2 & & & \\
\hline \multirow{3}{*}{ p3 } & $A 1$ & 15 & & & 4 & 20 & & 3 & 7 & 25 & & & \\
\hline & $A 2$ & 6 & & & 1 & 6 & & 2 & 1 & 5 & & 1 & \\
\hline & $A 3$ & & & & & & & & 1 & & & & \\
\hline \multicolumn{2}{|r|}{ Total } & 21 & 0 & 0 & 5 & 26 & & 5 & 9 & 30 & 0 & 1 & \\
\hline \multirow{3}{*}{$\mathrm{p} 4$} & $A 1$ & 3 & & & & & & & & 4 & & & \\
\hline & $A 2$ & 14 & 1 & & & & & & 5 & 25 & 1 & 1 & \\
\hline & $A 3$ & 6 & & & 7 & 19 & 1 & 7 & 6 & 1 & & & \\
\hline \multicolumn{2}{|r|}{ Total } & 23 & 1 & 0 & 7 & 19 & 1 & 7 & 11 & 30 & 1 & 1 & 0 \\
\hline \multirow{6}{*}{$\mathrm{m} 1^{*}$} & $A 2$ & & & & & & & 1 & & & & & \\
\hline & $B 1$ & 15 & & & 6 & 18 & & 1 & 7 & 27 & & 1 & \\
\hline & $B 2$ & 7 & & & 1 & 3 & & 6 & 4 & 16 & & & \\
\hline & $B 3$ & & & & & & & & & 2 & & & \\
\hline & $C 1$ & 1 & & & & 2 & & & 2 & 1 & & & \\
\hline & $C 2$ & & & & & & & 2 & 1 & 2 & & & 1 \\
\hline \multicolumn{2}{|r|}{ Total } & 23 & 0 & 0 & 7 & 23 & 0 & 10 & 14 & 48 & 0 & 1 & 1 \\
\hline \multirow{4}{*}{$\mathrm{m} 1^{* *}$} & $a 1$ & & & & & & & & & & & & \\
\hline & $a 2$ & 1 & & & & & & & 1 & & & & \\
\hline & $a 3$ & 6 & & & & 4 & & 1 & 6 & 3 & & & 1 \\
\hline & $a 4$ & 16 & & & & 15 & & 8 & 7 & 47 & & 1 & \\
\hline \multicolumn{2}{|r|}{ Total } & 23 & 0 & 0 & 0 & 19 & 0 & 9 & 14 & 50 & 0 & 1 & 1 \\
\hline
\end{tabular}


Table 2 (continued).

\begin{tabular}{|c|c|c|c|c|c|c|c|c|c|c|c|c|c|}
\hline \multirow{2}{*}{ Tooth } & \multirow{2}{*}{$\begin{array}{l}\text { Morpho- } \\
\text { type }\end{array}$} & \multicolumn{12}{|c|}{ Locality } \\
\hline & & 1 & 2 & 3 & 4 & 5 & 6 & 7 & 8 & 9 & 10 & 11 & 12 \\
\hline \multirow{2}{*}{$\mathrm{m} 2$} & $A 1$ & & & & 2 & 6 & & 2 & & 14 & & & \\
\hline & $A 2$ & & & & & & & & & 3 & & & \\
\hline \multicolumn{2}{|c|}{ Total } & & & & 2 & 6 & & 2 & & 17 & & & \\
\hline \multicolumn{2}{|c|}{$\begin{array}{l}\text { Number of } \\
\text { specimens }\end{array}$} & 69 & 1 & 4 & 21 & 78 & 1 & 28 & 44 & 175 & 1 & 6 & 3 \\
\hline
\end{tabular}

* — talonid morphotypes on $\mathrm{m} 1$ (previously described);

** _ metaconid morphotypes on $\mathrm{m} 1$ (new morphotypes).

Table 3. Frequency (\%) of diagnostic morphotypes on the marten teeth in modern samples and Holocene localities from Southern Urals and Trans-Urals.

\begin{tabular}{|c|c|c|c|c|c|c|c|}
\hline \multirow{2}{*}{ Tooth } & \multirow{2}{*}{ Morphotype } & \multicolumn{3}{|c|}{ Species* } & \multicolumn{3}{|c|}{ Locality** } \\
\hline & & 1 & 2 & 3 & 4 & 5 & 6 \\
\hline \multirow{8}{*}{ P4 } & $A 1$ & 40 & 58 & 58 & - & - & 36 \\
\hline & $A 2$ & 24 & 24 & 33 & - & - & 9 \\
\hline & $A 3$ & 9 & 10 & 3 & - & - & 32 \\
\hline & $A 4$ & 2 & 5 & 1 & - & - & 14 \\
\hline & $B 1$ & 3 & 2 & 21 & - & - & 0 \\
\hline & $B 2$ & 2 & 1 & 2 & - & - & 0 \\
\hline & $C$ & 5 & 0 & 0 & - & - & 0 \\
\hline & $D$ & 15 & 0 & 2 & - & - & 9 \\
\hline \multicolumn{2}{|r|}{$n$} & 530 & 660 & 120 & 0 & 0 & 22 \\
\hline \multirow{4}{*}{$\mathrm{p} 4$} & A1 & 2 & 3 & 4 & 13 & - & 13 \\
\hline & $A 2$ & 67 & 6 & 1 & 61 & - & 83 \\
\hline & $A 3$ & 25 & 90 & 95 & 26 & - & 3 \\
\hline & $B$ & 6 & 1 & 0 & & - & \\
\hline \multicolumn{2}{|r|}{$n$} & 530 & 660 & 120 & 23 & 0 & 30 \\
\hline \multirow{9}{*}{$\mathrm{m} 1$} & A1 & 0 & 0 & 55 & 0 & 0 & 0 \\
\hline & $A 2$ & 0 & 0 & 40 & 0 & 10 & 0 \\
\hline & $B 1$ & 5 & 24 & 1 & 65 & 10 & 56 \\
\hline & $B 2$ & 44 & 67 & 4 & 30 & 60 & 33 \\
\hline & B3 & 2 & 0 & 0 & 0 & 0 & 4 \\
\hline & $C 1$ & 2 & 1 & 0 & 4 & 0 & 2 \\
\hline & $C 2$ & 45 & 88 & 0 & 0 & 20 & 4 \\
\hline & $D 1$ & 1 & 0 & 0 & 0 & 0 & 0 \\
\hline & D2 & 1 & 0 & 0 & 0 & 0 & 0 \\
\hline \multicolumn{2}{|r|}{$n$} & 530 & 660 & 120 & 23 & 10 & 48 \\
\hline
\end{tabular}

* Recent samples: $1-$ M. zibellina, $2-$ M. martes, $3-$ M. foina

**Holocene localities: 4 - Mergen 6; 5 - Podpornaya, 6 - Atysh. 
sable passed here south $55^{\circ} \mathrm{N}$. The northeastern border of the area of the stone marten reached $54^{\circ} \mathrm{N}, 56^{\circ} \mathrm{E}$. Thus, in this part of the Southern Urals in the first half of the Late Holocene, the ranges of sable, stone marten and pine marten were overlapped. At the end of the late Holocene the sable range was shifted to the north, and the range of stone marten to the south-west. Since the 18 th century, only the pine marten inhabits the Southern Urals (Kirikov, 1959, 1960, 1966).

In the Southern Trans-Urals in the second half of the Holocene, the southern boundary of the sable area was south of $56^{\circ} \mathrm{N}$. In this area in the second half of the Holocene, the ranges of sable and pine marten were overlapped. The finds of the stone marten for this territory are not known. Thus, in the second half of the Holocene until the 18th century, the Southern TransUrals were inhabited by only two species of the genus Martes - sable and pine marten, their ranges were sympatric. Modern boundaries of the ranges of these species in the Southern Urals and in the Southern TransUrals have been formed over the last 300 years.

ACKNOWLEDGMENTS. The authors would like to thank G.F. Baryshnikov and M.V. Sablin (Zoological Institute, Russian Academy of Sciences), V.S. Lebedev (Zoological Museum of the Moscow State University), N.G. Erokhin and T.P. Kourova (Museum of the Institute of Plant and Animal Ecology, Russian Academy of Sciences) for giving access to the museum collections. The reported study was funded by RSF research project No.16-18-10332 and RFBR research project No.16-34-00364 mol-a and the Federal Agency for Scientific Organizations program for support the bioresource collections. The study of archaeological collections was conducted under the RSF project No.1618-10332.

\section{References}

Altuna J. 1973. Distinción craneal entre la Marta (Martes martes) y la Foina (M. foina) (Mammalia) // Munibe. Vol.25. No.1. P.33-38.

Ambros D. \& Hilpert B. 2005. Morphologische Unterscheidungsmerkmale an postcranialen Skelettelementen des Baummarders (Martes martes (Linné 1758)) und des Steinmarders (Martes foina (Erxleben 1777)) (Carnivora, Mustelidae) // Abhandlungen der Naturhistorischen Gesellschaft Nürnberg. No.45. S.19-34.

Aristov A.A. \& Baryshnikov G.F. 2001. [Mammals of Russia and adjacent territories. Carnivores and pinnipeds]. Saint Petersburg: Zoological Institute RAS. 560 p. [In Russian]

Devyashin M.M., Kosintsev P.A., Tyuten'kov O.Y., Ovodov N.D. \& Vasil'yev S.K. 2016. [Formation of contemporary ranges of martens (Martes Pinel, 1792) in the southeast of Western Siberia] // Zoologicheskii Zhurnal. Vol.95. No.6. P.728-738 [in Russian, with English summary].

Gasilin V.V. \& Gimranov D.O. 2010. [The species composition of the genus Martes in the Southern Urals in the
Holocene] // Dinamika sovremennykh ekosistem v golotsene. Materially II Rossiiskoi nauchoi konferentsii. Yekaterinburg, Chelyabinsk. P.65-67 [in Russian].

Gasilin V.V., Gimranov D.O. \& Kosintsev P.A. 2013. [The hunting of martens (Martes genus) by the population of Povolzhie and the Southern Urals in the Holocene] // Vestnik arkheologii, antropologii i etnografii. Vol.1. No.20. P.139-148 [in Russian, with English summary].

Gasilin V.V. \& Kosintsev P.A. 2013. [Identification of the subgenus Martes str. species (Martes zibellina, Martes martes, Martes foina, and Martes melampus) (Carnivora, Mustelidae) according to metric characteristics of mandible] // Zoologicheskii Zhurnal. Vol.92. No.2. P.221-230 [in Russian, with English summary].

Gasilin V.V., Kosintsev P.A., Razhev D.I. \& Fadeeva T.V. 2014. The geographic ranges of Martes species (Carnivora, Mustelidae) in the Middle Urals in the Late Pleistocene and Holocene // Biology Bulletin. Vol.41. No.8. P.672-680.

Gerasimov S. 1985. Species and sex determination of Martes martes and Martes foina by use of systems of craniometrical indices developed by stepwise discriminant analysis // Mammalia. Vol.49. No.2. P.235-248.

Gimranov D. \& Kosintsev P. 2015. Differentiation of three Martes species (M. martes, M. zibellina, M. foina) by tooth morphotypes // Comptes Rendus Palevol. Vol.14. No.8. P.647-656.

Heptner V.G., Naumov N.P., Yurgenson P.B., Sludskii A.A., Chirkova A.F. \& Bannikov A.G. 1967. [Mammals of the Soviet Union]. Vol.2. Part 1. Moscow: Vysshaya Shkola. 1004 p. [In Russian]

Khotinskiy N.A., Aleshinskaya Z.V., Guman M.A., Klimanov V.A. \& Cherkinskiy A.E. 1991. [New scheme of the periodization of landscape and climatic changes in the Holocene] // Izvestiya Akademii nauk SSSR. Seriya geograficheskaya. Vol.3. P.30-42 [in Russian].

Kirikov S.V. 1959. [Changes of the fauna in natural zones of the Soviet Union: the steppe zone and forest-steppe]. Moscow: Akademiya nauk SSSR. 175 p. [In Russian]

Kirikov S.V. 1960. [Changes of the of the fauna in natural zones of the Soviet Union: the forest zone and foresttundra]. Moscow: Akademiya nauk SSSR. 158 p. [In Russian]

Kirikov S.V. 1966. [Harvested animals, natural environment, and the man]. Moscow: Nauka. 348 p. [In Russian]

Kosintsev P.A. \& Bachura O.P. 2013. Late Pleistocene and Holocene mammal fauna of the Southern Urals // Quaternary International. Vol.284. P.161-170.

Kosintsev P.A. \& Gasilin V.V. 2011. [Historical changes of the north-eastern border of the stone marten geographic range (Martes foina Erxleben, 1777)] // Doklady Akademii Nauk. Vol.436. No.1. P.139-141 [in Russian].

Kosintsev P.A., Gasilin V.V., Gimranov D.O. \& Bachura O.P. 2016. Carnivores (Mammalia, Carnivora) of the Urals in the Late Pleistocene and Holocene // Quaternary International. Vol.420. P.145-155.

Loy A., Spinosi O. \& Carlini R. 2004. Cranial morphology of Martes foina and Martes martes (Mammalia, Carnivora, Mustelidae): the role of size and shape in sexual dimorphism and interspecific differentiation // Italian Journal Zoology. Vol.71. P.27-35. 
Miller G.S. 1912. Catalogue of the mammals of Western Europe in the collection of the British Museum. London: British Museum (Natural History). 1019 p.

Monakhov V.G. 2008. Chronological changes in cranial size in several populations of Martes zibellina // Martes Working Group Newsletter. Vol.16. No.1. P.9-10.

Monakhov V.G. 2012. Craniometry of Martes species in Russian Far East and Japan // Martes Working Group Newsletter. Vol.19. P.47-53.

Nasimovich A.A. (ed.). 1973. [Sable, martens, yellow-throated marten]. Moscow: Nauka. 238 p. [In Russian]

Ognev S.I. 1931. [Mammals of Eastern Europe and northern Asia. Vol.2]. Moscow, Leningrad: Gosizdat. 776 p. [In Russian]

Paaver K.L. 1965. [Formation of theriofauna and variation of mammals in the Baltic Region during the Holocene]. Tartu: Izdatel'stvo Akademii nauk Estonskoi SSR. 494 p. [In Russian]

Pallas P.S. 1786. [Journey over different provinces of the Russian State]. Saint Petersburg: Imperatorskaya Akademiya Nauk. Vol.2. Part 2. 575 p. [In Russian]

Pallas P.S. 1788. [Journey over different provinces of the Russian State]. Saint Petersburg: Imperatorskaya Akademiya Nauk. Vol.2. Part 3. 471 p. [In Russian]
Pavlinin V.N. 1963. [Tobolsk sable] // Trudy Instituta Biologii, Uralskii filial Akademii nauk SSSR. No.34. P.1112 [in Russian].

Ranyuk M.N. \& Monakhov V.G. 2011. [Variability of craniological characteristics in acclimatized sables (martes zibellina) populations] // Zoologicheskii Zhurnal. Vol.90. No.1. P.82-96 [in Russian, with English summary].

Ranyuk M.N. \& Monakhov V.G. 2015. [Comparative analysis of cranial variability Eurasian (sable and marten) and North American (American marten) Martes species] // Zoologicheskii Zhurnal. Vol.94. No.7. P.848-860 [in Russian, with English summary].

Smirnov N.G. 1975. [On the direction of the variability of the South Urals craniological signs marten in the Holocene] // Pavlinin V.N. (ed.). Populyatsionnaya izmenchivost' zhivotnykh. Sverdlovsk: UNC AN SSSR. P.98105 [in Russian].

Wolsan M. 1989. Dental polymorphism in the genus Martes (Carnivora: Mustelidae) and its evolutionary significance // Acta Theriologica. Vol.34. P.545-593.

Wolsan M., Ruprecht A.L. \& Buchalczyk T. 1985. Variation and asymmetry in the dentition of the pine and stone martens (Martes martes and M. foina) from Poland // Acta Theriologica. Vol.30. P.79-114. 